\title{
Does Entrepreneurship Affect Income Inequality within Countries? Direct and Indirect Effects in European Countries
}

\author{
Aleksandra Gaweł
}

\begin{abstract}
A B S T R A C T
Objective: The objective of the article is to verify the direct and indirect impact of entrepreneurship on income inequality within countries. Inequality has long been a problem for people, which appears as a consequence of unequal access to and distribution of wealth. The article implements the perspective of entrepreneurship into the discussion on inequality.
\end{abstract}

Research Design \& Methods: The research method is quantitative. Based on panel data of 26 European countries in years 2008-2018, regression functions are estimated to verify research hypotheses.

Findings: The direct influence of entrepreneurship measured by birth rate, death rate, and survival rate on inequality seems to be quite limited. However, the most important relationship is indirect impact through employment creation, which seems to reduce income inequality, especially regarding the employment of surviving companies.

Implications \& Recommendations: The employment share of surviving companies is an important variable that reduces income inequality; the entrepreneurship policy should concentrate on supporting the survival of newly created companies, not just on the start-up process.

Contribution \& Value Added: The novelty of the article is to implement the distinction between direct and indirect impact of entrepreneurship. The process of new company creation affects not only incomes of entrepreneurs but most importantly the indirect reduction of income inequality through employment. Moreover, the article sheds new light on the matter of inequality by the incorporation of time lag into analyses.

\begin{tabular}{|c|c|}
\hline $\begin{array}{l}\text { Article type: } \\
\text { Keywords: }\end{array}$ & $\begin{array}{l}\text { research article } \\
\text { entrepreneurship; start-up rate; survival rate; employment share; in- } \\
\text { come inequality; within inequality }\end{array}$ \\
\hline JEL codes: & L26, D63 \\
\hline Received: 24 & Accepted: 30 May 2020 \\
\hline
\end{tabular}

\section{Suggested citation:}

Gaweł, A. (2020). Does Entrepreneurship Affect Income Inequality within Countries? Direct and Indirect Effects in European Countries. Entrepreneurial Business and Economics Review, 8(2), 93-110. https://doi.org/10.15678/EBER.2020.080205 


\section{INTRODUCTION}

Equal income distribution is a dream that inspires humanity, it influences revolutions that treat equal wealth distribution as a sine qua non condition for freedom and dignity. Although today the capitalist system is generally accused of inducing inequality (Ragoubi \& El Harbi, 2018), in the historical age - meaning since the availability of written historical sources for a given area - social inequalities are noted in every civilisation. The problem of inequality holds the key position in philosophical debate, with private property being treated as the fundamental cause of inequality (Sunajko 2016). Observed inequalities led to the emergence and development of the concept of social classes. In a review of class theory, Luk'ianchikova and lamshchikova (2019) begin with the views of Plato, who indicated the existence of two states, one rich and one poor, both living and struggling together. Aristotle assumed the existence of three classes, the very rich, the very poor, and the middle class, among which the middle class is the optimal one, as its members are the most rational. Marx introduced the distribution of social classes based on the structure of production into work or property, while Max Weber later distinguished property (defining economic classes), power (defining political parties), and prestige (status groups) as three separate interacting factors that determine hierarchies in any society. Currently, the division of classes regards the status of occupation (employees, employers, and self-employed) or the share in the means of production (workers and capitalists or traditional and new middle class).

Due to the problem with access to historical data and their comparability, it is difficult to reliably determine the scale and variability of social inequalities throughout centuries. The question of inequality was a central topic of nineteenth-century economics, then in the twentieth century these issues became less important, while the past few years witness these matters regain their previous popularity (Mihalyi \& Szelenyi, 2017). Recently, the level of inequality in income distribution has been rising in most countries of the world as a consequence of the economic crisis (Sanchez \& Perez-Corral, 2018). Failure to reduce economic inequality could cause not only economic problems but also social erosion, which can in turn lead to less willingness of citizens to obey the law, make sacrifices during crises, or pay taxes (Ippolito \& Cicatiello, 2019; Malkina, 2019). European integration causes the narrowing of income equality across countries, but an increase in inequality within countries (Broll, Kemnitz, \& Mukherjee, 2019).

Despite the long discussion, scientific literature on inequality and its determinants is far from conclusive, offering fragmented explanation for the mixed evidence on inequality between and within countries (Dumont, Stojanovska, \& Cuyvers, 2011).

The main aspects of discussion on income inequality indicate the conflict of capitalists and employees in the creation of added value, in the distribution and concentration of wealth, and in sources and levels of income inequality. However, one more occupational group should be added to the discussion: entrepreneurs. Entrepreneurs are those persons who, to some extent, act as both capitalists and employees. Entrepreneurs invest their financial, social, and capital means in their companies by deciding on the use of all resources, thus fulfilling a capitalist role, but they simultaneously invest their own engagement, skills, experience, and other elements of human capital, thus fulfilling an employee's role.

The novelty of the article is to implement entrepreneurs into the discussion by distinguishing between direct and indirect impacts of entrepreneurship on income inequality. 
The direct influence is related to the wealth investment and income gained by entrepreneurs. The indirect impact of entrepreneurship is connected to employing workers by newly created and surviving companies, which reduces the income inequality through the salaries earned by employees.

Implementing entrepreneurs into the discussion on inequality raises several research questions. What are the mechanisms of entrepreneurs' impact on income inequality? Does starting a new business require financial investment and does entrepreneur engagement increase existing income inequality? Does the survival and development of the newly created company lead to deepening inequality through extra profits for entrepreneurs? Does the employment of employees during the development of a newly created company reduce income inequality through the employees' income creation?

The objective of this article is to verify the direct and indirect impact of entrepreneurship on income inequality within countries. Aiming to add an entrepreneurial viewpoint to the discussion, the structure of the article is the following. First, the article presents the existing perspectives on inequality. Then, I present the state of the art in the influence of entrepreneurship on inequality. The hypotheses on the direct and indirect impact of entrepreneurship appear in the next section of the article, together with the research method and results based on panel regression with random and fixed effects for 26 European countries in the years 2008-2017. The last section concludes research results.

\section{LITERATURE REVIEW}

\section{Inequality and Its Economic Explanation}

Traditionally perceived, human capital, financial capital, and natural resources are production factors, while income inequality and wealth inequality are to result from the conflict between employees and production factors' owners, which is the division of wealth and income. As GDP consists of incomes coming from two sources, labour and capital, there are two kinds of inequality. The first one is "within-inequality" for each of these sources of incomes, which means the inequality within labour income and inequality within capital income. The second type of inequality is "between-inequality," which relates to the split of GDP between capital and labour (Jones, 2015; Bilan, Mishchuk, Samoliuk, \& Yurchyk, 2020). The next distinction is inequality between countries, when the levels of inequality in different countries are compared, and inequality within countries, comparing level of inequality existing in a given economy (Dumont, Stojanovska, \& Cuyvers, 2011). The aim of the article is related to the inequality existing within country and the following discussion concentrates on this aspect.

Recently, discussion on income inequality was stimulated by Piketty's monograph (Polish edition 2015), which uses the historical perspective of long time series as the basis for analyses. In history, changes in the distribution of income between capital and labour were observed (Pikkety, 2015, p. 58), and - looking at data from the United Kingdom and France over the past 200 years - the share of income from capital in national income was about 30-50\%, while income from work approx. 60-70\% (Piketty, 2015, p. 247f). Moreover, a change in the nature of capital is observed: the importance of land and land capital dominating in the eighteenth century, for the benefit of real estate, industrial and financial capital in the twenty-first century (Piketty, 2015, p. 59). 
It seems that the greatest contribution of Thomas Piketty is to indicate the $r>g$ formula as the cause of income inequality, meaning that the rate of return on financial capital $r$ is greater than the rate of growth of national income $g$. The $r>g$ formula is a historical observation that in the eighteenth and nineteenth centuries, the economic growth rate was around $0.5-1 \%$ per year, and the growth rate from capital around $4-5 \%$ per year. If the rate of return on capital $r$ exceeds the rate of increase in income $g$, then inherited assets grow faster than the level of production and income, leading to a high concentration of capital. From the mathematical viewpoint, it was enough to save one-fifth of the income from capital and consume the remaining four-fifths so that the capital inherited from the previous generation would grow at the same pace as the economy (Piketty 2015, pp. 41f, 431-439).

Piketty's concept turned out to be very influential; on the one hand, for his supporters, it became a tool for explaining the dynamics of wealth and income inequality. On the other hand, it is strongly criticised (Madsen, Minniti, \& Venturini, 2018). Milovanović (2015) even calls Piketty's book a dangerous one, as it gives the impression that economic problems can be discussed without any economic theory, just by using simple logic.

For example, critics of Piketty's approach indicate his omission of capital depreciation. As the stock of capital depreciates over time, it is necessary to replace and increase the stock of capital by a sufficiently large portion of gross capital income, while the depreciation of capital results not only from its physical use but also from economic use (Rallo, 2018). Another issue raised by Piketty's critics is his assumption that the cause of rising income inequality between labour and capital is an elasticity of substitution between them in a production function greater than one. Meanwhile, the estimations made by Semieniuk (2017) for major world economies show that almost all single elasticity estimations are below 0.5 .

Further critique of Piketty's concept is that he ignores the impact of human capital on income inequality, focusing only on physical and financial capital (Kuehn, 2018), while human capital is the main economic growth factor in modern economy, and the impact of income distribution on economic development should be examined from the perspective of human capital accumulation instead of physical capital accumulation (Fan, Zhang, \& Liu, 2016). The rise of the middle class in the twentieth century proves that human capital is important in order to understand the accumulation of capital and concentration of wealth (Kuehn, 2018). The conflict of the division of wealth and income extends from the division between employees and owners of capital into the division between employees at various levels in the organisational structure of the company.

\section{Entrepreneurs, Capitalists, and Employees}

The aforementioned main aspects of the discussion on economic inequality point to the conflict between capitalists and employees in wealth creation and distribution. However, it seems that one more group of occupation should be added to the above dichotomy: entrepreneurs.

Determining the position of entrepreneurs in the distribution of income and wealth is not clear, since the definition of entrepreneurship has many dimensions (Rogalska, 2018). In the narrow sense, entrepreneurship is associated with the unique process of creation and the development of a new enterprise (Santarelli \& Vivarelli, 2007; Moroz \& Hindle, 2012), resulting from a long series of complex decision-making (Grilo \& Thurik, 2008). The creation of a new company requires the identification and acquisition of material and nonmaterial resources, while the initial set of resources not only affects the entrepreneurial 
process but also influences future access to other key resources (Hormiga, Batista-Canino, \& Sanchez-Medina 2011). A newly created company follows the start-up life cycle stages from the initial stage of bootstrapping, through the seed and creation stage, to the growth stage (Sekliuckiene, Vaitkiene, \& Vainauskiene, 2018), which means that the influence of entrepreneurship on income inequality can differ depending on life cycle stage.

To understand the differences in the position of employees and entrepreneurs, scholarship adopts the model of occupational choice, which assumes that an individual can either become a wage employee with a predictable and risk-free salary or an entrepreneur who makes entrepreneurial profit burdened with the risk of failure and of uncertain amount (among others: Kihlstrom \& Laffont, 1979; Bradley, 2016; Pardo \& Ruiz-Tagle, 2017; Krajčírová, Ferenzi Vaňová, \& Munk, 2019). The neoclassical approach of maximising utility is also applied, whereby the choice of occupation form is made rationally depending on the anticipated net profits. Rationality focuses on subjective determination, meaning the realisation of goals consistent with internal hierarchy of preferences (Krstić, 2014). The decision to become an entrepreneur happens when the individual finds that the benefits of becoming an entrepreneur outweigh the benefits of being a wage worker.

As both groups - entrepreneurs and wage workers - are heterogeneous (Brown, Farrell, \& Harris, 2011), the set of benefits and costs for each individual differ, which results in individual and unique decisions. There is a wide array of literature on determinants to become an entrepreneur (Rupasingha \& Goetz, 2013; Simoes, Crespo, \& Moreira, 2016; Crum \& Chen, 2015; Szarucki, Brzozowski, \& Stankevičienė, 2016; Coppola, lanuario, Chinnici, Di Vita, Pappalardo, \& D’Amico, 2018; Zygmunt, 2018; Dvorský, Petráková, Zapletalíková, \& Rózsa, 2019). Summing up these discussions, three groups of factors can be distinguished: socio-demographic factors, such as age structure, the share of men and women in labour force, the level of education; factors connected with the economic environment determining levels of costs and profits involved in running one's own company; and, finally, factors related to one's attitude towards entrepreneurship, showing one's readiness to become self-employed (Fritsch, Kritikos, \& Sorgner, 2015).

The important difference between being an entrepreneur and an employee is that starting one's own business requires investing not only in the human capital of the entrepreneur, but also his/ her financial capital and social network while working as an employee means engaging only human capital. Because of that, under the theory of occupational choice, access to financial capital is another group of determinants moderating the occupational decision (Seghers, Manigart, \& Uanacker, 2012; Reynolds, 2011). Individuals with broader access to more financial capital are more likely to become entrepreneurs; however, access to capital is influenced not only by the possessed wealth but also by an individual's ability to make savings, the levels of credit rating, or access to financial assets over a time horizon.

The entrepreneur's role is twofold. On the one hand, $s /$ he is the person who decides about the supply and use of company's resources but, on the other hand, s/he is treated as one of the resources. When establishing and running own company, an entrepreneur often invests own financial capital, which may bring him/her closer to the capitalist. However, especially with the currently growing market of private equity funds, the entrepreneur also works based on the investments of external investors, which may make him a manager of external capital to a greater extent than a capitalist. Already Schumpeter (1960) indicated 
the separation of entrepreneurial and capitalist functions by introducing the idea of the entrepreneur as the means of transforming the existing situation. Capitalism creates a tendency to think in certain ways, while "the entrepreneur" is a person who produces new combinations that lead to new products or new production methods. Schumpeter's entrepreneur is a dynamic newcomer who transforms the state of things (Joffe, 2017).

The entrepreneur is a person engaged in the creation and development of own business, while his/her human capital and engagement in the entrepreneurial process is one of the key success factors. The individual combination of entrepreneurs' human capital makes the entrepreneurial process unique. Entrepreneurs are an important part of human capital stock, while entrepreneurial activities are believed to have become a critical engine of global economic development, and income distribution might impact economic development through influencing the formation of entrepreneurs (Fan, Zhang, \& Liu, 2016).

\section{Occupational Choice Model of Entrepreneurship as Theoretical Background for Explaining Inequality}

The connections between entrepreneurship and inequality might be analysed from the input perspective, related to the investment of human, social and financial capital needed to be engaged by entrepreneurs and their access to them; or from the output perspective, related to differences in the level of entrepreneurial profits and employee wages. Both perspectives should be in line with distributive justice principles of a certain society (Mishchuk Samoliuk, \& Bilan, 2018). Empirical evidence suggests that entrepreneurship leads to wealth concentration, mostly due to the higher saving rates of entrepreneurs. A uniform increase in entrepreneurial income reduces per-capita household income inequality; however, an increase in the number of entrepreneurs does not affect inequality (Kimhi, 2010). Inequality is also claimed to be the outcome of an intergenerational externality, as current entrepreneurs who are physical-capital formation agents bequeath their wealth to descendants who act in fact as rentiers rather than as entrepreneurs (Soldatos, 2017). Descendants use the capital rather to get the capital income than to actively run a company.

The literature shows some examples of using the occupational choice model to analyse income inequality. Fan, Zhang, and Liu (2016) propose a theoretical model in which individuals make an occupation choice between three: unskilled worker, skilled worker, and entrepreneur. An unskilled worker enters the traditional sector and joins the labour force, with the individual's wealth being the sum of income, parental transfer, and interest on savings. A skilled worker needs to acquire a formal education with a fixed cost and then he enters the modern sector. The wealth of a skilled worker is the sum of wage income and the interest income from savings or reduced by the interest payment for borrowing for education. An entrepreneur also needs to acquire formal education with a fixed cost, then enter the modern sector to organise production by hiring skilled workers with a competitive wage and equipment of some units of physical capital. This means that an entrepreneur must have an initial investment of physical capital and human capital. The results show that the presence of entrepreneurs impacts income distribution by affecting the composition of human capital; they generate the demand for skilled workers and encourage workers to invest in their education, thereby improving the level of income per capita (Fan, Zhang, \& Liu, 2016).

Another model expands occupation choices to workers and entrepreneurs who operating in the domestic market or entrepreneurs who operate on the global market, depending on managerial talent. Individuals are driven by expected income maximisation, 
whereby individuals with low managerial talent become workers; individuals with intermediate managerial talent become entrepreneurs who act in the domestic market and receive middle-class income; while highly talented individuals become entrepreneurs who operate in the global market and receive higher incomes (Dinopoulos \& Unel, 2017). Therefore, entrepreneurship influences income inequality.

The research results presented above assume that entrepreneurship and entrepreneurial activity are factors that affect income inequality. However, there also are studies on the inverse relationship, meaning the impact of income inequality on entrepreneurship (Ragoubi \& El Harbi, 2018; Mishchuk, Samoliuk, \& Bilan, 2019). Jung, Seo, and Jung (2018) prove the hypothesis that income inequality negatively affects regional economic performance by decreasing entrepreneurial activities. The authors assume that income inequality negatively affects both entrepreneurship and economic growth as the result of insufficient demand for new products/services. Results show as well that the income situation of entrepreneurs is not equal, self-employed entrepreneurs generally have lower incomes than paid workers while incorporated self-employed have higher income than other groups (Halvarsson, Korpi, \& Wennberg, 2018).

The connections between entrepreneurship and inequality might also depend on involvement in productive or unproductive activities, which are linked with the institutional environment and the reward structure of the economy. Productive entrepreneurs expand the size of the economy through their wealth-generating activities, with their wealth and income redirected towards productive investments in the form of reinvested profits or loans. Unproductive entrepreneurs seek rent and accumulating non-productive assets (Wiseman \& Young, 2014; Rovira, 2015). There might be a difference between the influence of productive and unproductive entrepreneurs on inequality, but this impact is not considered in this article.

Summing up the discussion, entrepreneurs can be the group whose activity will affect income inequality in both direct and indirect ways. Direct impact is connected with the business activity of entrepreneurs who seek to generate their profits by investing in human, social, and financial capital. Starting a new business requires initial investment, effort, and time to get to the break-even point, which means that the initial investment in the starting stage of a company's existence might contribute to widening inequality by decreasing the entrepreneur's income, both from their own work and the income from assets allocated for establishing a company. If the newly created company survives on the market and begins to generate income for the entrepreneur, then the impact on income inequality depends on the difference in the level of entrepreneurial income and employee remuneration, but also in the way of reinvesting income in the development of the enterprise and its fixed assets. On the other hand, if a company closes down, it may cause a loss of income for both the entrepreneurs themselves and their employees, but it may also cause the depreciation of the value of the company's fixed assets, aggravating income inequalities. Therefore, we may formulate the following hypotheses:

H1: Start-up rate directly influences the increase of income inequality.

H2: Survival rate directly influences the reduction of income inequality.

H3: Death rate directly influences the increase of income inequality.

However, entering into entrepreneurship often entails hiring employees and becoming an employer, which differentiates entrepreneurs-employers from the self-employed 
(Bennett \& Rablen, 2015). The need to hire employees can trigger indirect impacts of entrepreneurship on income inequality. An entrepreneur creates jobs and generates wages for employees, thus he can contribute to the equalisation of incomes for different social groups. These theoretical assumptions allow us to posit the following research hypotheses:

H4: The employment share of start-up companies indirectly influences the reduction of income inequality.

H5: The employment share of survival rate indirectly influences the reduction of income inequality.

\section{MATERIAL AND METHODS}

To verify the hypotheses, I conducted the following research. The general relationship between entrepreneurship and inequality is assumed to follow the equations (1) and (2):

where:

$$
\begin{gathered}
I E_{i t}=\beta_{0}+\beta_{1} E N_{i t}+v_{i t} \\
I E_{t+1}=\beta_{0}+\beta_{1} E N_{i t}+v_{i t}
\end{gathered}
$$

$$
\begin{aligned}
& I E_{i t} \text { - dependent variable describing income inequality in } t \text { period and in } i \\
& \text { country; } \\
& I E_{t+1} \text { - dependent variable describing income inequality in } t+1 \text { period and in } i \\
& \text { country; } \\
& E N_{i t} \text { - independent variables describing entrepreneurship in } t \text { period and in } i \\
& \text { country; } \\
& \beta_{0}, \beta_{1} \text { - vectors; } \\
& v_{i t} \text { - total random error consisting of a purely random part } \varepsilon_{j t} \text { and individual ef- } \\
& \text { fect } u_{i} \text { referring to the specific } i \text { unit of the panel }\left(v_{i t}=\varepsilon_{j t}+u_{i}\right) .
\end{aligned}
$$

All relationships assumed in the research hypotheses might occur both immediately in the same period of time (equation 1) and with a lag of one period of time (equation 2).

I designated two measures as dependent variables describing income inequality as the most commonly used measures of inequality: the Gini index (GINI) and the Inequality of Income Distribution (IID). According to Eurostat, the Gini coefficient (GINI) is understood as the relationship of cumulative shares of the population - arranged according to the level of equivalised disposable income - to the cumulative share of the equivalised total disposable income received by them. The Gini index is believed to be the most informative indicator of social inequality (Sanchez \& Perez-Corral, 2018); the greater the indicator, the more unequally the incomes are distributed in a society. The Gini index is also calculated for different countries, which allows researchers to conduct cross-country analysis (Luk'ianchikova \& lamshchikova, 2019). According to Eurostat, the inequality of income distribution (IID) is measured as the ratio of total income received by the $20 \%$ of the population with the highest income to that received by the $20 \%$ of the population with the lowest income.

The direct impact of entrepreneurship on inequality is connected with the creation of new companies, their survival on the market and their death (hypotheses $\mathrm{H} 1, \mathrm{H} 2$; and $\mathrm{H} 3$ ). Three measures were accepted: birth rate (BR) shows the share of newly created companies in the total number of active companies, death rate (DR) is a ratio of enterprise deaths in total number of active companies, while survival rate 2 (SR2) indicates the 
share of enterprises in the reference period $t$ newly born in $t-2$, having survived to $t$ divided by the number of enterprise births in $t-2$, meaning companies that survived the first two years of existence.

The indirect impact is measured by the influence of employment engaged by newly created or surviving companies (hypotheses $\mathrm{H} 4$ and $\mathrm{H} 5$ ). The first indicator here is the employment share of enterprise births (ESBR), which shows the share of persons employed among newly born enterprises, divided by the number of persons employed among all active enterprises. The second indicator is the employment share of two-year-old enterprises (ESSR2), which shows the share of persons employed in newly born enterprises in $t-2$, having survived to $t$ (survived the first two years of existence), divided by the number of persons employed in the population of active enterprises in $t$.

The initial equations ( 1 ) and (2) differ in time lag. The process of new company creation is time-consuming, which allows the assumption that some time lags may occur in the relationship between the creation of new companies and income inequality. The assumption of one period of time lag is accepted a priori.

To estimate the parameters of regression functions and, hence, to verify the research hypotheses, I gathered data from 26 European countries published by Eurostat. The selection criterion was the availability of data, which led me to use yearly data in the period of 2008-2017 from the following countries: Austria, Belgium, Bulgaria, Cyprus, Czechia, Denmark, Estonia, Finland, France, Germany, Hungary, Ireland, Italy, Latvia, Lithuania, Luxembourg, Netherlands, Norway, Poland, Portugal, Romania, Slovakia, Slovenia, Spain, Sweden, the United Kingdom. This allows for the creation of two panels of data: based on equation 1, a panel of ten years 2008-2017 and 26 countries; and, based on equation 2, a panel of ten years $2009-2018$ and 26 countries.

The first step in the analysis was to calculate the cross-correlation among data (table 1). The correlation coefficients are mostly positive ones, at around 0.4-0.5 value. The only negative correlated measures are inequality measures and survival rate over two years.

Table 1. Correlation coefficients among indicators of inequality and entrepreneurship

\begin{tabular}{|c|c|c|c|c|c|}
\hline \multicolumn{7}{|c|}{ Correlation in period t } \\
\hline Indicator & BR & DR & SR2 & ESBR & ESSR2 \\
\hline GINI & 0.422 & 0.497 & -0.325 & 0.471 & 0.495 \\
\hline IID & 0.432 & 0.501 & -0.321 & 0.494 & 0.530 \\
\hline \multicolumn{7}{|c|}{ Correlation in period t+1 } \\
\hline Indicator & BR & DR & SR2 & ESBR & ESSR2 \\
\hline GINI & 0.413 & 0.515 & -0.319 & 0.471 & 0.489 \\
\hline IID & 0.420 & 0.510 & -0.312 & 0.496 & 0.528 \\
\hline
\end{tabular}

Source: own study.

To linearise the relationships between data, all data were converted to natural logarithms, and then I used Gretl software to estimate panel regression in three steps: using the method ordinary least squares (OLS), panel regression with random effects (RE), and panel regression with fixed effects (FE). The values of the Breusch-Pagan test and the Hausman test led me to a conclusion about the correctness of these three methods and indicate the most proper one. Next, the statistical significance of independent variable parameters based on 
p-value validated the research hypotheses. Results of all three methods of estimation are presented to indicate whether the results vary depending on the method, although the verification of hypotheses is conducted based on the most relevant regression method.

\section{RESULTS AND DISCUSSION}

The first estimations verify the equation (1) with relationship in a given time period. Results of regression function estimations are presented in Table 2. Based on the Breusch-Pagan test, we may state that - in the cases of all functions -panel regression was a better method than OLS. Based on the Hausman test, panel regression with fixed effects (FE) was indicated as the better method in three regressions (InGINI depending on InESBR and InESSR2; InIIG depending on InBR and InDR; InIIG depending on InESBR and InESSR2). The panel regression with random effects (RE) was a better estimation method in the case of the next three functions (InGINI depending on InBR and InDR; InGINI depending on InSR; InIIG depending on InSR). The next step was to analyse the pvalue of parameters in the selected functions. Whenever it was at the acceptable level (0.05), the regression function was accepted. If the p-value was higher than (0.05), the statistically insignificant parameter was rejected, and the function was estimated again, or the function was rejected at once. After introducing this procedure, three regression functions were finally accepted for the verification of research hypotheses.

The first estimation treats the InGINI index as a dependent variable and explains its changes with $\ln B R$ as an independent variable. Analysing the value of regression parameter, the influence of InBR on InGINI is a positive one, the increase (decrease) of birth rate influences the increase (decrease) of income inequality measured by the GINI index. The second accepted function assumes the InGINI to be a dependent variable and InESSR2 to be an independent variable. Looking at the value of parameter, the relationship is a negative one, the increase (decrease) of employment share in survival companies influences the decrease (increase) of income inequality measured by the GINI index. The last accepted function treats InIIG as a dependent variable, which is explained by InESSR2 as an independent variable. The relationship is also a negative one; whenever the employment share in survival companies goes up (down), it influences the decrease (increase) of income inequality measured by the index of the Inequality of Income Distribution (IID). The analysis of adjustment measures and significance levels allow for the acceptance of the following regression functions:

$$
\begin{gathered}
\operatorname{lnGINI}_{i t}=3.303+0.034 \ln B R_{i t} \\
\ln G I N I_{i t}=3.408-0.032 \ln E S S R 2_{i t} \\
\operatorname{lnIID_{it}}=1.591-0.056 \ln E S S R 2_{i t}
\end{gathered}
$$

The second approach of the research is that the reaction of income inequality with changes in entrepreneurship requires one period of time, so that the regression function (2) assumes the one-year lag. The results of regression function estimations are presented in Table 3. Based on the Breusch-Pagan test, we may state that in the cases of all functions, panel regression was a better method than OLS. Based on the Hausman test, panel regression with fixed effects (FE) was indicated as a better method in four regressions (InGINI depending on InBR and InDR; InGINI depending on InESBR and InESSR2; InIIG depending on InBR and InDR; InIIG depending on InESBR and InESSR2). Panel regression with random effects 
(RE) was a better estimation method in the case of the next two functions (InGINI depending on InSR; InIIG depending on InSR). After analysing the $p$-value, the regression functions were accepted ( $p$-value<0.05), estimated again, or rejected ( $p$-value $>0.05)$. After introducing this procedure, two regression functions were finally accepted for analysis.

Table 2. Regression functions estimated in t period

\begin{tabular}{|c|c|c|c|}
\hline Variable & OLS & $\mathrm{FE}$ & RE \\
\hline \multicolumn{4}{|c|}{ Dependent variable $(Y)$ : InGINI } \\
\hline $\begin{array}{l}\begin{array}{l}\text { const } \\
\text { InBR } \\
\text { InDR }\end{array} \\
\text { Fit measures }\end{array}$ & $\begin{array}{c}2.942 * * * \\
0.103 * * * \\
0.099 * * * \\
\mathrm{R}^{2}=0.572 ; \\
\text { Adjusted } \mathrm{R}^{2}=0.569 \\
\mathrm{~F}(2,252)=168.404\end{array}$ & $\begin{array}{c}3.313 * * * \\
0.028 \\
0.001 \\
\text { LSDV } R^{2}=0.936 \\
\text { LSDV } \mathrm{F}(27,227)= \\
121.976\end{array}$ & $\begin{array}{c}3.303^{* * *} \\
0.034^{*} \\
\cdot \\
\text { Breusch-Pagan Test } \\
p<0.0001 \\
\text { Hausman Test } \mathrm{p}=0.0891\end{array}$ \\
\hline $\begin{array}{c}\text { const } \\
\text { InSR2 } \\
\text { Fit measures }\end{array}$ & $\begin{array}{c}4.664^{* * *} \\
-0.304^{* * *} \\
\mathrm{R}^{2}=0.319 ; \\
\text { Adjusted } \mathrm{R}^{2}=0.316 \\
\mathrm{~F}(1,250)=116.932 \\
\end{array}$ & $\begin{array}{c}3.534 * * * \\
-0.037 \\
\text { LSDV } \mathrm{R}^{2}=0.937 \\
\text { LSDV } \mathrm{F}(26,225)= \\
128.147 \\
\end{array}$ & $\begin{array}{c}3.568^{* * *} \\
-0.044 \\
\text { Breusch-Pagan Test } \\
p<0.0001 \\
\text { Hausman Test } p=0.0806 \\
\end{array}$ \\
\hline $\begin{array}{c}\text { const } \\
\text { InESBR } \\
\text { InESSR2 }\end{array}$ & $\begin{array}{c}3.220 * * * \\
0.090 * * * \\
0.079 * * * \\
\mathrm{R}^{2}=0.593 \\
\text { Adjusted } \mathrm{R}^{2}=0.589 \\
\mathrm{~F}(2,245)=178.195 \\
\end{array}$ & $\begin{array}{c}3.408 * * * \\
- \\
-0.032 * \\
\text { LSDV } \mathrm{R}^{2}=0.943 \\
\text { LSDV } \mathrm{F}(26,222)= \\
140.653\end{array}$ & $\begin{array}{c}3.395^{* * *} \\
0.007 \\
-0.021 \\
\text { Breusch-Pagan Test } \\
p<0.0001 \\
\text { Hausman Test } p=0.0027\end{array}$ \\
\hline \multicolumn{4}{|c|}{ Dependent variable (Y): InIID } \\
\hline $\begin{array}{c}\text { const } \\
\text { InBR } \\
\text { InDR } \\
\text { Fit } \\
\text { measures }\end{array}$ & $\begin{array}{c}0.835 * * * \\
0.140 * * * \\
0.178^{* * *} \\
\mathrm{R}^{2}=0.616 \\
\text { Adjusted } \mathrm{R}^{2}=0.613 \\
\mathrm{~F}(2,252)=201.793\end{array}$ & $\begin{array}{c}1.492^{* * *} \\
0.031 \\
-0.010 \\
\text { LSDV } R^{2}=0.935 \\
\text { LSDV F(27, 227) = } \\
120.608\end{array}$ & $\begin{array}{c}1.442^{* * *} \\
0.043 \\
0.001 \\
\text { Breusch-Pagan Test } \\
p<0.0001 \\
\text { Hausman Test } p=0.0081\end{array}$ \\
\hline $\begin{array}{l}\text { const } \\
\text { InSR2 }\end{array}$ & $\begin{array}{c}3.757^{* * *} \\
-0.527^{* * *}\end{array}$ & $\begin{array}{c}1.862 * * * \\
-0.076\end{array}$ & $\begin{array}{c}1.919 * * * \\
-0.089 \\
\end{array}$ \\
\hline $\begin{array}{c}\text { Fit } \\
\text { measures }\end{array}$ & $\begin{array}{c}R^{2}=0.359 ; \\
\text { Adjusted } R^{2}=0.357 \\
F(1,250)=140.085\end{array}$ & $\begin{array}{c}\text { LSDV R } R^{2}=0.936 \\
\text { LSDV } F(26,225)= \\
126.348\end{array}$ & $\begin{array}{c}\text { Breusch-Pagan Test } \\
p<0.0001 \\
\text { Hausman Test } p=0.0795\end{array}$ \\
\hline $\begin{array}{c}\text { const } \\
\text { InESBR } \\
\text { InESSR2 } \\
\text { Fit } \\
\text { measures }\end{array}$ & $\begin{array}{c}1.260 * * * \\
0.154 * * * \\
0.136 * * * \\
\mathrm{R}^{2}=0.531 ; \\
\text { Adjusted } \mathrm{R}^{2}=0.527 \\
\mathrm{~F}(2,245)=138.491\end{array}$ & $\begin{array}{c}1.593 * * * \\
- \\
-0.056 * \\
\text { LSDV } \mathrm{R}^{2}=0.943 \\
\text { LSDV } \mathrm{F}(26,222)= \\
141.062\end{array}$ & $\begin{array}{c}1.573^{* * *} \\
-0.002 \\
-0.031 \\
\text { Breusch-Pagan Test } \\
p<0.0001 \\
\text { Hausman Test } p=0.0003\end{array}$ \\
\hline
\end{tabular}

* In bold: models accepted for hypotheses verification.

Significant codes: ${ }^{* * *} p<0.001 ;{ }^{* *} p<0.01 ;{ }^{*} p<0.05$.

Source: own elaboration. 
Table 3. Regression functions estimated in $\mathrm{t}+1$ time

\begin{tabular}{|c|c|c|c|}
\hline Variable & OLS & $\mathrm{FE}$ & RE \\
\hline \multicolumn{4}{|c|}{ Dependent variable (Y): InGINI in period $t+1$} \\
\hline $\begin{array}{c}\begin{array}{c}\text { const } \\
\text { InBR } \\
\text { InDR }\end{array} \\
\text { Fit measures }\end{array}$ & $\begin{array}{c}2.962^{* * *} \\
0.070^{* * *} \\
0.125^{* * *} \\
\mathrm{R}^{2}=0.576 ; \\
\text { Adjusted } \mathrm{R}^{2}=0.572 \\
\mathrm{~F}(2,249)=168.922\end{array}$ & $\begin{array}{c}3.320 * * * \\
0.005 \\
0.024 \\
\text { LSDV } \mathrm{R}^{2}=0.933 \\
\text { LSDV } \mathrm{F}(27,224)= \\
115.614\end{array}$ & $\begin{array}{c}3.317^{* * *} \\
\cdot \\
0.030^{*} \\
\text { Breusch-Pagan Test } \\
p<0.0001 \\
\text { Hausman Test } p=0.0067\end{array}$ \\
\hline $\begin{array}{c}\text { const } \\
\text { InSR2 } \\
\text { Fit } \\
\text { measures }\end{array}$ & $\begin{array}{c}4.653^{* * *} \\
-0.301 * * * \\
\mathrm{R}^{2}=0.293 ; \\
\text { Adjusted } \mathrm{R}^{2}=0.291 \\
\mathrm{~F}(1,248)=102.963\end{array}$ & $\begin{array}{c}3.426 * * * \\
-0.011 \\
\text { LSDV } \mathrm{R}^{2}=0.932 \\
\text { LSDV F(26, 223) }= \\
117.813\end{array}$ & $\begin{array}{c}3.464^{* * *} \\
-0.019 \\
\text { Breusch-Pagan Test } \\
p<0.0001 \\
\text { Hausman Test } p=0.0608\end{array}$ \\
\hline $\begin{array}{c}\text { const } \\
\text { InESBR } \\
\text { InESSR2 } \\
\text { Fit } \\
\text { measures }\end{array}$ & $\begin{array}{c}3.219^{* * *} \\
0.107^{* * *} \\
0.067^{* *} \\
\mathrm{R}^{2}=0.547 \\
\text { Adjusted } \mathrm{R}^{2}=0.543 \\
\mathrm{~F}(2,245)=146.529\end{array}$ & $\begin{array}{c}3.414^{* * *} \\
-0.036 * \\
\text { LSDV } \mathrm{R}^{2}=0.932 \\
\text { LSDV } \mathrm{F}(26,220)= \\
116.680\end{array}$ & $\begin{array}{c}3.404^{* * *} \\
\cdot \\
-0.023 \\
\text { Breusch-Pagan Test } \\
p<0.0001 \\
\text { Hausman Test }=0.0005\end{array}$ \\
\hline \multicolumn{4}{|c|}{ Dependent variable $(\mathrm{Y}): \ln I I D$ in period $t+1$} \\
\hline $\begin{array}{c}\text { const } \\
\text { InBR } \\
\text { InDR } \\
\text { Fit } \\
\text { measures }\end{array}$ & $\begin{array}{c}0.831^{* * *} \\
0.120^{* * *} \\
0.204^{* * *} \\
\mathrm{R}^{2}=0.615 \\
\text { Adjusted } \mathrm{R}^{2}=0.612 \\
\mathrm{~F}(2,249)=198.651\end{array}$ & $\begin{array}{c}1.539 * * * \\
-0.010 \\
0.014 \\
\text { LSDV } R^{2}=0.934 \\
\text { LSDV } \mathrm{F}(27,224)= \\
116.759\end{array}$ & $\begin{array}{c}1.484^{* * *} \\
0.002 \\
0.026 \\
\text { Breusch-Pagan Test } \\
p<0.0001 \\
\text { Hausman Test } p=0.0078\end{array}$ \\
\hline $\begin{array}{c}\text { const } \\
\text { InSR2 } \\
\text { Fit } \\
\text { measures }\end{array}$ & $\begin{array}{c}3.686^{* * *} \\
-0.509 * * * \\
\mathrm{R}^{2}=0.362 ; \\
\text { Adjusted } \mathrm{R}^{2}=0.360 \\
\mathrm{~F}(1,248)=140.771\end{array}$ & $\begin{array}{c}1.720 * * * \\
-0.041 \\
\text { LSDV } \mathrm{R}^{2}=0.934 \\
\text { LSDV } \mathrm{F}(26,223)= \\
120.477\end{array}$ & $\begin{array}{c}1.781^{* * *} \\
-0.056 \\
\text { Breusch-Pagan Test } \\
p<0.0001 \\
\text { Hausman Test } p=0.0677\end{array}$ \\
\hline $\begin{array}{c}\text { const } \\
\text { InESBR } \\
\text { InESSR2 } \\
\text { Fit } \\
\text { measures }\end{array}$ & $\begin{array}{c}1.254^{* * *} \\
0.182^{* * *} \\
0.119^{* * *} \\
\mathrm{R}^{2}=0.572 ; \\
\text { Adjusted } \mathrm{R}^{2}=0.569 \\
\mathrm{~F}(2,243)=162.604\end{array}$ & $\begin{array}{c}1.613^{* * *} \\
-0.073^{* *} \\
\text { LSDV } \mathrm{R}^{2}=0.936 \\
\text { LSDV } \mathrm{F}(26,220)= \\
124.239\end{array}$ & $\begin{array}{c}1.590^{* * *} \\
\cdot \\
-0.047 \\
\text { Breusch-Pagan Test } \\
p<0.0001 \\
\text { Hausman Test } p<0.0001\end{array}$ \\
\hline
\end{tabular}

* In bold: models accepted for hypotheses verification. Significant codes: ${ }^{* * *} p<0.001 ;{ }^{* *} p<0.01 ;{ }^{*} p<0.05$. Source: own elaboration.

Both measures of income inequality as dependent variables are explained by InESSR2 as the independent variable in a negative manner. The increase (decrease) of employment in survival companies (ESSR2) influences the decrease (increase) of both GINI index (GINI) and the Inequality of Income Distribution (IID) as measures of income inequality. These relationships can be presented in the following two regression functions: 


$$
\begin{aligned}
& \ln G I N I_{i t+1}=3.414-0.036 \ln E S S R 2_{i t} \\
& \ln I I D_{i t+1}=1.6013-0.073 \ln E S S R 2_{i t}
\end{aligned}
$$

To summarise, among entrepreneurship measures of direct impact, death rate (DR) seems to not influence the income inequality measures as such a relationship is statistically insignificant. It means that research hypothesis 3 is rejected. Moreover, the survival rate over two years (SR2) has no statistically significant impact on income inequality. Out of four estimated set of regressions, SR2 does not explain the changes in income inequality in a significant manner. Thus, hypothesis 2 is rejected.

Birth rate as an entrepreneurship measure of direct impact has a limited influence on income inequality and both of them only where the current period of time is concerned. According to the estimation of regression function, out of four analysed relationships, birth rate (BR) significantly impacts just one regression function. BR looks to influence as positively on the GINI index as the income inequality measure (function 3), meaning that the higher the birth rate, the higher the income inequality level. I assume that this relationship is associated with a decrease in entrepreneurs' incomes at the initial stage of creating a new company. Establishing a new company requires, on the one hand, the investment of human, financial and social capital, and on the other hand, as a rule, only after some time of running a new business does its market position establish enough that the founding entrepreneur can count on income from his involvement. It means that hypothesis 1 finds limited support here and requires further investigation.

The strongest impact of entrepreneurship seems to be in regard to the employment shares of surviving companies (ESSR2). Out of four estimated set of equations, ESSR2 was a statistically significant variable in all cases, explaining the income inequality measured both by the GINI (functions 4 and 6) and the IID indexes (functions 5 and 7). The impact of ESSR2 on the GINI and IID measures is negative; the increase (decrease) of ESSR2 influences the decrease (increase) of income inequality. These results allow for the acceptance of hypothesis 5, assuming that the employment share of surviving companies reduces income inequality. Mostly during the first months of the market existence of start-up companies, the entrepreneurs who establish companies work by themselves with some help of family and friends and try not to employ any workers, which explains why the employment share of birth rate (ESBR) does not influence GINI or IID. It means that hypothesis 4 is rejected, as it assumes the impact of employment share of newly created companies. However, after surviving the first two critical years of existence on the market, companies are mature and established enough to employ workers and pay them salaries, which leads to the reduction of income inequality. Moreover, we may assume that the shape of the ESSR2 index is influenced not only by the companies that survive on the market but also by those who have a relatively high intention for development, manifested in the employment of employees. These companies rely not only on the personal work of founding entrepreneurs but also generate employment for external persons. Thus, they indirectly reduce income inequality by influencing the income of employees. This influence is valid not only in the current period of time but also when one year of time lag is considered. All these results give support for accepting hypothesis 5 . 


\section{CONCLUSIONS}

Inequality has a long history and has been discussed since ancient times. However, the novelty of the article is to implement the perspective of entrepreneurship into this discussion and the direct and indirect impact of entrepreneurs on income inequality. The direct influence was assumed to be related to wealth investment and income gained by entrepreneurs. The indirect impact of entrepreneurship is connected with employing workers by newly created and surviving companies, which reduces income inequality through salaries earned by employees.

Based on data from 26 European countries in years 2008-2018, I examined the research hypotheses with the use of panel regression modelling. The results show that the direct influence of entrepreneurship on income inequality seems limited. Death rate and survival rate do not influence income inequality in a statistically significant manner, while birth rate impacts inequality only to a certain extent. Birth rate by the initial financial and human investments of entrepreneurs partly increases the level of inequality by reducing the incomes of entrepreneurs in the initial stage of company creation. However, the most important relationship is the indirect one, which seems to reduce income inequality, especially regarding the employment of surviving companies. The employment share of surviving companies is an important variable that reduces income inequality. The newly created companies that survived on the market through the most critical time begin to employ workers in the development stage. Thus, income inequality lowers thanks to entrepreneurial incomes and the salary growth of employees.

The research findings also give recommendations for entrepreneurship policy. To support social cohesion, the policy should concentrate on supporting the survival of newly created companies, not just on the start-up process, as it leads to reducing income inequality.

The limitation of this research is it exclusive focus on countries from Europe, which necessitates further research in other parts of the world with different levels of equality. Another limitation is that data from all European countries were taken together into one panel, so distinguishing countries with different characteristics and analysing relationships separately in groups of similar features can also be a possible path for further investigation.

\section{REFERENCES}

Bennett, J., \& Rablen, M.D. (2015). Self-employment, wage employment, and informality in a developing economy. Oxford Economic Papers, 67(2), 227-244. https://doi.org/10.1093/oep/gpu047

Bilan, Y., Mishchuk, H., Samoliuk, N., \& Yurchyk, H. (2020). Impact of Income Distribution on Social and Economic Well-Being of the State. Sustainability, 12(1), 429. https://doi.org/10.3390/su12010429

Bradley, J. (2016). Self-employment in an equilibrium model of the labor market. IZA Journal of Labor Economics, 5(6), https://doi.org/10.1186/s40172-016-0046-8

Broll, U., Kemnitz, A., \& Mukherjee, V. (2019). Globalization, inequality and economic policy. Economics and Business Review, 19(1), 3-11. https://doi.org/10.18559/ebr.2019.1.1

Brown, S., Farrell, L., \& Harris, M.N. (2011). Modelling The Incidence of Self-Employment: Individual and Employment Type Heterogeneity. Contemporary Economic Policy, 29(4), 605-619. https://doi.org/10.1111/J.1465-7287.2010.00232.X 
Coppola, A., Ianuario, S., Chinnici, G., Di Vita, G., Pappalardo, G., \& D‘Amico, D. (2018). Endogenous and Exogenous Determinants of Agricultural Productivity: What Is the Most Relevant for the Competitiveness of the Italian Agricultural Systems?. AGRIS on-line Papers in Economics and Informatics, 10(2), 33-47. https://doi.org/10.7160/aol.2018.100204.

Crum, M., \& Chen, Y. (2015). Self-Employment and Subjective Well-Being: A Multi-Country Analysis. International Journal of Entrepreneurship, 19, 15-28.

Dinopoulos, E., \& Unel, B. (2017). Managerial capital, occupational choice and inequality in a global economy. Canadian Journal of Economics / Revue canadienne d'économique, 50(2), 365-397.

Dumont, M., Stojanovska, N., \& Cuyvers, L. (2011). World inequality, globalisation, technology and labour market institutions. International Journal of Manpower, 32(3), 257-272. https://doi.org/10.1108/01437721111136750

Dvorský, J., Petráková, Z., Zapletalíková, E., \& Rózsa, Z. (2019). Entrepreneurial propensity index of university students. The case study from the Czech Republic, Slovakia and Poland. Oeconomia Copernicana, 10(1), 173-192. https://doi.org/10.24136/oc.2019.009

Fan, Z., Zhang, R., \& Liu, X. (2016). Income inequality, entrepreneur formation, and the economic development: evidence from China. Journal of The Asia Pacific Economy, 21(3), 444-464. https://doi.org/10.1080/13547860.2016.1176646

Fritsch, M., Kritikos, A.S., \& Sorgner, A. (2015). Why did self-employment increase so strongly in Germany?. Entrepreneurship \& Regional Development, 27(5-6), 307-333. https://doi.org/10.1080/08985626.2015.1048310

Grilo, I., \& Thurik, R.( 2008). Determinants of entrepreneurial engagement levels in Europe and the US. Industrial and Corporate Change, 17(6), 1113-1145.

Halvarsson, D., Korpi, M., \& Wennberg, K. (2018). Entrepreneurship and income inequality. Journal of Economic Behavior \& Organization, 145, 275-293. https://doi.org/10.1016/j.jebo.2017.11.003

Hormiga, E., Batista-Canino, R.M., \& Sanchez-Medina, A. (2011). The Impact of Relational Capital on the Success of New Business Start-ups. Journal of Small Business Management, 49(4), 617-638.

Ippolito, M., \& Cicatiello, L. (2019). Political Instability, Economic Inequality and Social Conflict: The Case in Italy. Panoeconomicus, 66(3, Special Issue), 365-383. https://doi.org/10.2298/PAN1903365I

Joffe, M. (2017). Evidence and the micro-foundations of economic growth. Economics and Business Review, 17(3), 52-79. https://doi.org/10.18559/ebr.2017.3.410.18559/ebr.2017.3.4

Jones, Ch.I. (2015). Pareto and Piketty: The Macroeconomics of Top Income and Wealth Inequality. Journal of Economic Perspectives, 29(1), 29-46. https://doi.org/10.1257/jep.29.1.29

Jung, H., Seo, I., \& Jung, K. (2018). Mediating Role of Entrepreneurship in Explaining the Association Between Income Inequality and Regional Economic Performance. Economic Development Quarterly, 32(2), 135-145. https://doi.org/10.1177/0891242418758438

Kihlstrom, R.E., \& Laffont, J.-J. (1979). A General Equilibrium Entrepreneurial Theory of Firm Formation Based on Risk Aversion. Journal of Political Economy, 87(4), 719-748. https://doi.org/10.1086/260790

Kimhi, A. (2010). Entrepreneurship and income inequality in southern Ethiopia. Small Business Economics, 34, 81-91. https://doi.org/10.1007/s11187-009-9196-4

Krajčírová, R., Ferenzi Vaňová, A., \& Munk, M. (2019). What Is Relationship between Profits and Dividends in Agricultural Legal Entities?. AGRIS on-line Papers in Economics and Informatics, 11(1), 55-64. https://doi.org/10.7160/aol.2019.110106

Krstić, M. (2014). Rational Choice Theory and Addiction Behavior. Market-TRžIŠTE, XXVI(2), 163-177.

Kuehn, D. (2018). Human Capital in the Twenty First Century. The European Journal of Comparative Economics, 15(1), 3-9. https://doi.org/10.25428/1824-2979/201801-3-9 
Luk'ianchikova, T., \& lamshchikova, T. (2019). The Theory and Reality of Social Inequality. Russian Social Science Review, 60(5-6), 496-506. https://doi.org/10.1080/10611428.2019.1676079

Madsen, J.B., Minniti, A., \& Venturini, F. (2018). Assessing Piketty's second law of capitalism. Oxford Economic Papers, 70(1), 1-21. https://doi.org/10.1093/oep/gpx040

Malkina, M. (2019). Spatial wage inequality and its sectoral determinants: the case of modern Russia. Oeconomia Copernicana, 10(1), 69-87. https://doi.org/10.24136/oc.2019.004

Mihalyi, P., \& Szelenyi, I. (2017). Wealth and capital: a critique of Piketty's conceptualisation of return on capital. Cambridge Journal of Economics, 41, 1237-1247. https://doi.org/10.1093/cje/bew054

Milovanović, M. (2015). Thomas Piketty's Capitalism Revisited. Panoeconomicus, 62(5), 663-677. https://doi.org/10.2298/PAN1505663M

Mishchuk, H., Samoliuk, N., \& Bilan, Y. (2019). Measuring social justice in the light of effectiveness of public distributive policy. Administration \& Public Management Review, (32). 63-76. https://doi.org/10.24818/amp/2019.32-05

Mishchuk H., Samoliuk N., Bilan Y., Streimikiene D. (2018). Income inequality and its consequences within the framework of social justice. Problemy Ekorozwoju, 13(2), 131-138.

Moroz, P.W., \& Hindle, K. (2012). Entrepreneurship as a Process: Towards Harmonizing Multiple Perspectives. Entrepreneurship: Theory and Practice, 36(4), 781-818.

Pardo, C., \& Ruiz-Tagle, J. (2017). The dynamic role of specific experience in the selection of selfemployment versus wage-employment. Oxford Economic Papers, 69(1), 189-212. https://doi.org/10.1093/oep/gpw047

Piketty, T. (2015). Kapitał w XXI wieku. Warsaw: Wydawnictwo Krytyki Politycznej.

Rogalska, E. (2018). Multiple-criteria analysis of regional entrepreneurship conditions in Poland. Equilibrium. Quarterly Journal of Economics and Economic Policy, 13(4), 707-723. https://doi.org/10.24136/eq.2018.034

Ragoubi, H., \& El Harbi, S. (2018). Entrepreneurship and income inequality: a spatial panel data analysis. International Review of Applied Economics, 32(3), 374-422. https://doi.org/10.1080/02692171.2017.1342776

Rallo, J.R. (2018). Some Fundamental Problems with Thomas Piketty's."Capital in the Twenty-First Century". The Independent Review, 22(4), 599-607.

Reynolds, P.D. (2011). Informal and Early Formal Financial Support in the Business Creation Process: Exploration with PSED II Data Set. Journal of Small Business Management, 49(1), 27-54.

Rovira, J.R. (2015). Piketty on Growth and Distribution. Hacienda Publica Espanola / Review of Public Economics, 214(3), 91-114. https://doi.org/10.7866/HPE-RPE.15.3.4

Rupasingha, A., \& Goetz, S.J. (2013), Self-employment and local economic performance: Evidence from US counties. Papers in Regional Science, 92(1), 141-162. https://doi.org/10.1111/j.14355957.2011.00396.x

Sanchez, A., \& Perez-Corral, A.L. (2018). Government Social Expenditure and Income Inequalities in the European Union. Hacienda Pública Espańola / Review of Public Economics, 227(4), 133-156. https://doi.org/10.7866/HPE-RPE.18.4.5

Santarelli, E., \& Vivarelli, M. (2007). Entrepreneurship and the process of firms' entry, survival and growth. Industrial and Corporate Change, 16(3), 455-488.

Schumpeter, J. (1960). Teoria rozwoju gospodarczego. Warszawa: PWN.

Seghers, A., Manigart, S., \& Uanacker, T. (2012). The Impact of Human and Social Capital on Entrepreneurs' Knowledge of Finance Alternatives. Journal of Small Business Management, 50(1), 63-86. 
Sekliuckiene, J., Vaitkiene, R., \& Vainauskiene, V. (2018). Organisational Learning in Startup Development and International Growth. Entrepreneurial Business and Economics Review, 6(4), 125144. https://doi.org/10.15678/EBER.2108.060407

Semieniuk, G. (2017). Piketty's Elasticity of Substitution: A Critique. Review of Political Economy. 29(1), 64-79. https://doi.org/10.1080/09538259.2016.1244916

Simoes, N., Crespo, N., \& Moreira, S.B. (2016). Individual Determinants of Self-Employment Entry: What Do We Really Know?. Journal of Economic Survey, 30(4), 783-806. https://doi.org/10.1111/joes.12111

Soldatos, G.T. (2017). Inheritance and inequality, and aggregate demand and policy issues. International Journal of Social Economics, 44(12), 1833-1845. https://doi.org/10.1108/IJSE-01-2016-0021

Sunajko, G. (2016). Rawls and Piketty: the philosophical aspects of economic inequality. The Journal of Philosophical Economics: Reflections on Economic and Social Issues, IX(2), 71-84.

Szarucki, M., Brzozowski, J., \& Stankevičienè, J. (2016). Determinants of Self-Employment Among Polish and Romanian Immigrants in Germany. Journal of Business Economics and Management, 17(4), 598-612. https://doi.org/10.3846/16111699.2016.1202313

Wiseman, T., \& Young, A. (2014). Religion: productive or unproductive?. Journal of Institutional Economics, 10(1), 21-45. https://doi.org/10.1017/S174413741300026X

Zygmunt, J. (2018). Entrepreneurial activity drivers in the transition economies. Evidence from the Visegrad countries. Equilibrium. Quarterly Journal of Economics and Economic Policy, 13(1), 89103. https://doi.org/10.24136/eq.2018.005 


\section{Author}

\section{Aleksandra Gaweł}

Professor of economics at the Poznan University of Economics and Business. She is the author or co-author of over 120 publications, her research includes areas of entrepreneurship, entrepreneurial education, innovation, business cycle, labour market, and regional development.

Correspondence to: Prof. Aleksandra Gaweł, Poznan University of Economics and Business, Department of International Competitiveness, al. Niepodległości 10, 61-875 Poznan, Poland, e-mail: aleksandra.gawel@ue.poznan.pl

ORCID (1) http://orcid.org/0000-0002-7426-3474

\section{Acknowledgements and Financial Disclosure}

The preparation of the article was funded by Poznan University of Economics and Business.

\section{Copyright and License}

() (1) 9

This article is published under the terms of the Creative Commons

Attribution - NoDerivs (CC BY-ND 4.0) License

http://creativecommons.org/licenses/by-nd/4.0/

\section{Published by the Centre for Strategic and International Entrepreneurship - Krakow, Poland}

